\title{
$(\mathrm{cc}) \mathrm{BY}$
}

UDC 658.264

DOI:10.30724/1998-9903-2019-21-3-73-85

\section{MATHEMATICAL MODELING OF THE FORECAST AND STANDBY HEATING MODES}

\author{
V.A. $\operatorname{Tarasov}^{1}$, V.V. $\operatorname{Tarasova}^{2}$, V.V. Afanasyev ${ }^{1}$, V.G. Kovalev ${ }^{1}$, V.N. Orlov ${ }^{1}$ \\ ${ }^{1}$ Chuvash State University, Cheboksary, Russia \\ ${ }^{2}$ LLC Engineering and Technical Center GORISS, Cheboksary, Russia
}

\begin{abstract}
The aim of the work is the development and study of methods for reducing the cost of heat energy for heating buildings and constructions by means of usage of automated control systems based on a programmable logic controller. Methods: In contrast to the known methods, the proposed mathematical model of non-stationary processes in heat-intensive enclosures makes it possible, according to the adaptive control algorithm, to perform forecast and standby heating taking into account the time dependence of the outdoor air temperature. Results: The algorithm ensures the equality of the heating system power and the heat losses power, allows one to maintain the desired indoor air temperature in the room when the outdoor air temperature changes. The heat loss compensation mode is achieved without using the temperature chart parameters of the network water and the parameters of proportional-integral-differential control laws that are necessary to set up at common automatic heating control systems. When calculating the forecast and standby heating modes, the mathematical model allows, at given initial and final temperatures of the internal air, determining the heating system power, which provide the desired temperature at the end of a specified period of time. The adaptive control algorithm allows setting the calculated outdoor temperature and the desired internal air temperature at any time. Under the forecast control, the mathematical model allows determining the system power at which the internal air temperature will remain almost constant when the outdoor air temperature changes. Conclusions: The developed algorithm of adaptive control allows one to create an energy-efficient heating system that provides the desired room temperature with minimum consumption of thermal energy taking into account all parameters affecting the heat loss power and the heating system power.
\end{abstract}

Keywords: mathematical model, power of the heating system, forecast temperature, outside air, forecast control, standby heating, adaptive control algorithm, programmable logic controller.

For citation: Tarasov VA, Tarasova VV, Afanasyev VV, Kovalev VG, Orlov VN. Mathematical modeling of the forecast and standby heating modes. Power engineering: research, equipment, technology. 2019; 21(3):73-85. (In Russ). doi:10.30724/1998-9903-2019-21-3-73-85.

\section{МАТЕМАТИЧЕСКОЕ МОДЕЛИРОВАНИЕ РЕЖИМОВ ПРОГНОЗНОГО И} ДЕЖУРНОГО ОТОПЛЕНИЯ

\author{
В.А. Тарасов $^{1}$, В.В. Тарасова ${ }^{2}$, В.В. Афанасьев ${ }^{1}$, В.Г. Ковалев ${ }^{1}$, В.Н. Орлов ${ }^{1}$ \\ ${ }^{1}$ Чувашский государственный университет им. И.Н.Ульянова, г.Чебоксары, \\ Россия \\ ${ }^{2}$ ООО «Инженерно-технический центр ГОРИСС», г.Чебоксары, Россия
}


Резюме. Цель: Целью работы является разработка и исследование методов снижения затрат тепловой энергии на отоплениезданий и сооружений за счет применения систем автоматизированного управления

Методы: Методом математического моделирования нестационарных тепловых прочессов в системах отоплениясозданаметодика расчета режимов прогнозного и дежурного отопления и алгоритмадаптивного управления системой отопления, который реализован на программируемом логическом контроллере. В отличие от известных методов предложенная математическая модель нестациинарных процессов в теплоемких ограждениях позволяет осуществлять по алгоритму адаптивного управления прогнозное и дежурное отопление с учетом изменения во времени температуры наружного воздуха. Результать: Алгоритм обеспечивает равенство мощуности системь отопления и мощуности тепловых потерь, позволяетподдерживать заданную температуру внутреннего воздуха в помещении при изменениитемпературы наружного воздуха. Выход на режим компенсаџии тепловых потерь достигается без использования параметров температурного графика сетевой водь и параметров пропоричонально-интегральнодифференциальных законов регулирования, которые необходимы для настройки широко распространенных систем автоматического управления отоплением. При расчете режимов прогнозного и дежурного отопления математическая модель позволяет при заданных начальных и конечных температурах внутреннего воздуха определить значения мощности системь отопления, обеспечивающие желаемую температуру в конце заданного промежутка времени. Алгоритм адаптивного управления позволяет в любой момент времени задатьзначения расчетной температуры наружного воздуха и требуемой температуры внутреннего воздуха.При прогнозном управлении математическая модель позволяет определить значения мощности системы,при которых температура внутреннего воздуха будет оставаться практически постоянной при изменении температуры наружного воздуха.

Выводы: Разработанный алгоритм адаптивного управления позволяет создать энергоэффективную систему отопления, обеспечивающую при минимальном расходе тепловой энергии заданную температуру в помещениях здания с учетом всех параметров, влияющих на мощуность тепловых потерь и мощунсть системы отопления.

Ключевые слова: математическая модель, мощностьсистемы отопления, прогнозная температура, наружный воздух,прогнозное отопление,дежурноеотопление, алгоритм адаптивного управления, программируемый логический контроллер.

\section{Introduction}

In developed countries, the global energy crisis of the 70 s of the 20th century accelerated the development and implementation of energy-saving technologies, contributed to a large-scale structural economy reorganization to reduce the share of energy-intensive industries by their transfer to developing countries. All of this taken over the past quarter of the 20th century led to a decrease in the energy intensity of economy in developed countries by 2-2.5 times. The policy of energy-saving and energy efficiency continues in the 21 st century. According to the State report on the state of energy-saving and energy efficiency in the Russian Federation in 2017 (http://www. economy. gov.ru) over the past ten years, the energy intensity of the economy of the advanced countries has decreased by $15-20 \%$, while the previously adopted plans are being revised towards tightening. For example, by 2020 it is planned to reduce the economy energy intensity in the United States by $25 \%$ as compared to that in 2005, in the EU countries by $20 \%$ as compared to that in 2007, and in the P. R. China by $49 \%$ as compared to that in 2006 . Therefore, the task of energy saving and improving energy efficiency for our country is very relevant. 
Buildings and constructions are among the main consumers of heat energy, which account for up to $20 \%$ of the total balance of global energy consumption [1]. According to the Forecast of the scientific and technological development of the sectors of the fuel and energy complex of Russia for the period up to 2035 (https://www/minenergo.gov.ru) the centralized heat supply systems form the core of heat supply in Russia, the share of which in the total volume of heat energy production reaches $82 \%\left(1.3 \cdot 10^{9} \mathrm{Gcal}\right.$ per year). The expert estimations show that the housing and utilities sector solely, excluding the budget sphere, accounts for about $20 \%$ of the total energy saving potential in the Russian Federation [2]. At the same time, in the public sector, about $82 \%$ of the total amount of operated buildings have a reduced, low and very low energy efficiency class, which indicates a significant potential for energy saving in this sector. One of the most efficient ways to reduce the consumption of thermal energy for heat supply is the automation of heating systems and the improvement of heat supply control algorithms [3,4,5].

In Russia, the regulation of the heat supply regime of the vast majority of buildings and constructions is carried out centrally from the heat source (boiler room, CHP) according to the temperature schedule of network water supply depending on the outdoor temperature. In this case, control is carried out depending on factors common to all buildings in the area of heat supply source. The group stage of regulation has a similar drawback, when management is carried out from factors common to fewer buildings [6,7,8,9].

Thus, centralized and group heating control systems do not take into account the individual static and dynamic heating characteristics of individual buildings, the effects of insolation and wind, do not enable efficient management of heat carrier parameters, and the organization of forecast and standby heating. Therefore, they often do not provide optimal temperature regime in the premises and result in irrational overspending of thermal energy, especially in autumn and spring. The technological capabilities of individual heat points (IHP) with automatic weather regulation are much higher, since they allow one to take into account almost all the factors affecting a single building. Therefore, the task of increasing the energy efficiency in the heat supply of buildings can be solved only by widespread introduction of IHP with automatic weather regulation $[8,10,11,12]$.

The aim of this work is to develop a mathematical model of the unsteady thermal regime of a building, which describes the dynamics of real processes occurring in buildings and constructions during the transition from one state to another, taking into account the actual specific heating characteristics of the enclosing structures, the thermal inertia of buildings, external disturbances in the form of outdoor temperature air changes [4.13]. The model is implemented in an adaptive heating system control algorithm for a programmable logic controller (PLC).

\section{Materials and methods}

The object of simulation is a centralized heat supply system of a typical four-story educational building D of Chuvash State University, consisting of a heating station, main supply and outlet pipes, stacks and connections to heating units, as well as shut-off and control valves. The housing is supplied with heat in accordance with the temperature schedule $130 / 70{ }^{\circ} \mathrm{C}$. The IHP scheme includes forced pump circulation with coolant mixing from the return pipe $[4,13]$. The automatic weather control system includes: PLC-150 programmable logic controller, water temperature sensors in the supply line, at the inlet and outlet of the heating system, outdoor and indoor air temperature sensors, electromagnetic water flow converter, full pressure transmitters at the inlet and outlet of heat point, circulation pump that controls a two-way valve with an electric actuator. Signals from the sensors enter the control cabinet for further processing by the controller and its peripherals. The main thermo-technical characteristics of the case are: mass of heatresistant enclosures $M=1460 \mathrm{t}$; the average heat capacity of the heat-resistant enclosure material $c=800 \mathrm{~J} /(\mathrm{kg} \cdot \mathrm{K})$; the generalized thermal characteristic of the building, determined by the statistical processing of data from an automated heat point [4], $q V=2.843 \mathrm{~kW} / \mathrm{K}$; indoor heat transfer coefficient $\alpha_{v}=7.8 \mathrm{~W} /\left(\mathrm{m}^{2} \cdot \mathrm{K}\right)$, outdoor winter heat transfer coefficient $\alpha_{n}=23 \mathrm{~W} /\left(\mathrm{m}^{2} \cdot \mathrm{K}\right)$; time constant: $T=1.728 \cdot 10^{5} \mathrm{~s}=48$ hours. 
Comfortable conditions in the premises with minimum consumption of heat energy for heating are achieved at the heat balance of the building or construction, when the heating system provides compensation for heat losses taking into account technological and domestic heat and insolation. To calculate the forecast and standby heating modes and the emergency response modes for heating, it is necessary to study the relationship between the temperatures of indoor and outdoor air and the power of the heating system during non-stationary processes.

In order to ensure a predetermined air temperature inside a heated room, the actual power of the heating system $P_{\text {heat }}$ should compensate the calculated heat loss of the building $P_{\text {loss }}$, taking into account the technological and domestic heat energy input into the heated building, as well as insolation.

The calculated heat loss power depends on the thermal characteristics of the building and the temperatures of the indoor and outdoor air:

$$
P_{\text {loss }}=q V\left(t_{\text {calc.in }}-t_{\text {calc.out }}\right)
$$

where $V$ is the external total structural volume of the building; $q$ is the specific heating characteristic of the building, which should take into account the real thermophysical characteristics of the enclosures, the shape and orientation of the building, the infiltration and the wind impact. The product $q V$ is a generalized thermal characteristic of the building.

The difference between the actual or desired temperature of the air inside the building and the continuously measured actual or set outdoor temperature $\left(t_{\text {calc.in }}-t_{\text {calc.out }}\right)$ is the main disturbing factor for the heating system. The heating system power required to compensate heat loss depends on the temperatures of the direct and return water and the water flow in the heating system:

$$
P_{\text {heat }}=G_{2} \rho c\left(t_{\text {dir }}-t_{\text {ret }}\right)=P_{\text {loss }}-P_{\text {ext }},
$$

where $G_{2}$ is the volume water consumption in the building heating circuit; $\rho$ is water density; $c$ is the specific water heat capacity; $t_{\mathrm{dir}}, t_{\text {ret }}$ are the temperatures of direct and return water in the building heating circuit; $P_{\text {ext }}$ is the power of technological and domestic heat sources including insolation.

The most common method of heating system control is to control perturbation (according to the temperature of the outdoor air or using the temperature difference between the indoor and outdoor air). The control system may provide feedback using the temperature of coolant entering the building, or using the coolant temperature in the return pipe $[3,5,6]$. In this case, only coolant temperatures are usually used, through which, using a number of assumptions, the power of the heating system is determined by mathematical modeling. High-quality control by changing the temperatures of the direct and return water in accordance with the temperature schedule with a constant flow rate of water cannot fully compensate heat losses, since the influence of wind and insolation is not taken into account. The network water temperature at the heat source is determined by the air temperature for a certain period, taking into account the forecast and the available heat capacity of the source. Transport lag leads to a mismatch between the consumer network water temperature and the current outdoor temperature. In addition, the heat source often fails to comply with the temperature schedule of the network water, therefore widespread heating control algorithms that use only the temperature of the external and internal air, as well as the water temperature in the heating pipes and heating systems cannot provide timely and full compensation of heat losses. It should also be noted that for the implementation of well-known control algorithms for network water temperature, reference points of the heating system schedule and parameter values of proportional-integral and proportional-integral-differential laws of regulation are necessary. 
The existence of water flow meters in modern heating centers allows one to determine the actual heating system power and to perform control not according to the temperature schedule, but directly by the power of the heating system, based on equality (2) using the adaptive control algorithm [4,13].

The algorithm for adaptive heat supply of buildings and construction, created on the basis of the automated heat point of building D, Chuvash State University, which takes into account weather, climatic and functional conditions, is implemented in the CODESYS environment on the PLC-150 programmable logic controller with registration and visualization of all measured and calculated values at an automatic operator workstation (AOW) [4]. The algorithm provides a quick access to the mode of compensation for heat loss without using the parameters of the network water temperature schedule and the parameters of proportional-integral and proportional-integraldifferential laws of regulation $[4,13]$.

To study the dynamics of thermal processes in heating systems, a model based on the heat balance of internal air and enclosures using quasistationary approximations can be applied [14]. The differential heat balance equation for the temperature of the internal air has the form [14] when written using the notation adopted in the theory of automatic control:

$$
T_{\text {in_air }} \frac{d t_{\text {in_air }}}{d \tau}+t_{\text {in_air }}=k P_{\text {heat }}+T_{\text {out_air }} \frac{d t_{\text {out_air }}}{d \tau}+t_{\text {out_air }},
$$

where $T_{\text {in_air }}$ is the time constant for the indoor air temperature $t_{\text {in_air }} ; T_{\text {out_air }}$ is the time constant for the outdoor air temperature $t_{\text {out_air }} ; P_{\text {heat }}$ is the actual power of the heating system; $k=1 / q V$ is the coefficient for transmission via the channel "heating system power - indoor air temperature".

The product of the building specific heating characteristic $q$ and the external total structural volume of the building $V$ is a generalized thermal characteristic $q V$ that can be determined by statistical processing of metering nodes data [4]. The time constant $T_{\text {in_air }}$ can be expressed in terms of mass of heat-resistant enclosures and the generalized thermal characteristic $q V$ :

$$
T_{\text {in_air }}=\frac{c M}{2 q V} U,
$$

where $c$ is the average specific heat of heat-resistant enclosures; $U$ is the correction factor taking into account the difference in the values of heat transfer coefficients from the outer surface of the wall to the outside air $\alpha_{\text {outair }}$ and from the inner air to the inner surface of the wall $\alpha_{\text {in_air }[14]:}$

$$
U=\frac{R_{\text {wall }}+2 R_{\text {out_air }}}{R_{\text {in_air }}+R_{\text {wall }}+R_{\text {out_air }}},
$$

where $R_{\text {wall }}=\delta / \lambda$ is the wall thermal resistance; $R_{\text {in_air }}=1 / \alpha_{\text {in_air }}$ is the resistance to heat transfer from internal air to the inner surface of the wall; $R_{\text {out_air }}=1 / \alpha_{\text {out_air }}$ is the resistance to heat transfer from the outer surface of the wall to the outside air

In stationary mode at heat loss compensation:

$$
P_{\text {heat }}=P_{\text {loss }}=q V\left(t_{\text {calc.in }}-t_{\text {calc.out }}\right)
$$

In non-stationary modes, with forecast control and standby heating, the actual power of the heating system may differ from the heat loss power

$$
P_{\text {heat }}=K P_{\text {loss }} \text {. }
$$


Equation (3) is easily solved for the time-independent outdoor air temperature [14]. However, in reality, this temperature can vary significantly, which must be taken into account when calculating the forecast, standby and emergency control heating modes $[15,16]$. To simulate the cooling or warming processes, it was assumed that the outdoor temperature at the initial time $\tau=0$ is equal to $t_{\text {out_air } 0}$, and then began to change in time according to the law

$$
t_{\text {out_air }}=B \tau^{2}+t_{\text {out_air0 }}, B=\frac{t_{\text {out_airk }}-t_{\text {out_air0 }}}{\tau_{k}^{2}},
$$

where $t_{\text {out_air0 }}, t_{\text {out_airk }}$ are the outdoor temperatures at the beginning and end of the period $\tau_{k}$. In addition, the outdoor air temperature change rate at the initial time is zero. In this case, $B<0$ for the predicted cooling, $B>0$ for the predicted warming and $B=0$ for the constant outdoor air temperature.

For this law of the outdoor temperature change in time, equation (3) has the form

$$
T_{\text {in_air }} \frac{d t_{\text {in_air }}}{d \tau}+t_{\text {in_air }}=k P_{\text {heat }}+2 T_{\text {out_air }} B \tau+B \tau^{2}+t_{\text {out_air0 }} \text {. }
$$

The initial conditions for solving equation (4) are:

$$
\tau=0, t_{\text {in_air }}=t_{\text {in_air0 }}, t_{\text {out_air }}=t_{\text {out_air0 }} .
$$

The solution of equation (4) under the initial conditions (5) has the form

$$
t_{\text {in_air }}(\tau)=C \exp \left(-\frac{\tau}{T_{\text {in_air }}}\right)+y(\tau),
$$

where $C=t_{\text {in_air0 }}-2 B T_{\text {in_air }}{ }^{2}+2 B T_{\text {in_air }} T_{\text {out_air }}-K\left(t_{\text {in_air0 }}-t_{\text {out_air0 }}\right)-t_{\text {out_air0 }}$;

$$
\begin{aligned}
& y(\tau)=B \tau^{2}-2 B T_{\text {in_air }} \tau+2 B T_{\text {in_air }}{ }^{2}+2 B T_{\text {out_air }} \tau-2 B T_{\text {in_air }} T_{\text {out_air }}+ \\
& +K\left(t_{\text {in_air0 }}-t_{\text {out_air0 }}\right)+t_{\text {out_air0 }}
\end{aligned}
$$

In the particular case for the stationary mode with $B=0$ and $K=1$, the actual power of the heating system is equal to the heat loss power

$$
P_{\text {heat }}-P_{\text {ext }}=P_{\text {loss }} \text {. }
$$

If the actual power of the heating system is greater than the heat loss power, the temperature of the internal air will increase, if it is less, the temperature of the internal air will decrease. The internal air temperature change rate depends on the coefficient $K$. When the heating is turned off and $K=0$, the mathematical model allows estimating the temperature cooling time inside the room taking into account changes in the temperature of the outdoor air.

During non-working hours (holidays, weekends and night time), the temperature of the indoor air can be reduced by decreasing the heating power to the standby heating mode in order to reduce heating costs. To ensure a decrease or an increase in air temperature from temperature $t_{\text {in_air0 }}$ to a predetermined level $t_{\text {in_airk }}$ during time $\tau_{k}$, the power of the heating system $P_{\text {heat }}$ is determined from solution of the following equation with respect to the coefficient $K$ $t_{\text {in_airk }}\left(\tau_{k}\right)=C \exp \left(-\frac{\tau_{k}}{T_{\text {in_air }}}\right)+y\left(K, \tau_{k}, t_{\text {in_air0 }}, t_{\text {in_airk }}\right)$.

Then, the calculated power of the heating system is determined as

$$
P_{\text {heat }}=K P_{n} \text {, }
$$

where $P_{n}$ is the power at the beginning of the room temperature cooling or heating period. 


\section{Results}

The proposed mathematical model makes it possible to determine the coefficient $K$ for a given indoor air cooling or heating rate and the required power of the heating system during standby heating, taking into account the outdoor air temperature change in time. Tables 1 and 2 show the calculations results for changes in heating power and heat energy consumption during two days when switching to standby heating mode and vice versa, and also without switching to standby mode at a constant outdoor temperature $t_{\text {out_air }}=-15^{\circ} \mathrm{C}$ (Table 1) and when changing outdoor temperature from $t_{\text {out_air }}=-15{ }^{\circ} \mathrm{C}$ to $-17{ }^{\circ} \mathrm{C}$ (Table 2). It can be concluded that the specific value of thermal energy savings due to standby heating on non-working days substantially depends on the outdoor air temperature and for $t_{\text {out_air }}=-15{ }^{\circ} \mathrm{C}$ it is $11 \%$. The calculation data show that when the heating is completely turned off and the outdoor temperature is $-15{ }^{\circ} \mathrm{C}$, the air in the room will cool down to $14.6^{\circ} \mathrm{C}$ in 8 hours (Fig. $2 a$, curve 2). If the outdoor air temperature during this period decreases to $-17^{\circ} \mathrm{C}$, then the indoor air will cool down to $12.6^{\circ} \mathrm{C}$ (Fig. $2 a$, curve 3), and if the outdoor temperature rises to $-13^{\circ} \mathrm{C}$, the indoor temperature will decrease for only $3.4^{\circ} \mathrm{C}$.

Table 1

Changes in the heating system power and the thermal energy consumption at a constant outdoor temperature $t_{\text {out_air }}=-15^{\circ} \mathrm{C}$

\begin{tabular}{|l|c|c|c|}
\hline \multicolumn{1}{|c|}{ Mode } & $\begin{array}{c}\text { Time, } \\
\text { hours }\end{array}$ & $\begin{array}{c}\text { Heating } \\
\text { system } \\
\text { power, } \mathrm{kW}\end{array}$ & $\begin{array}{c}\text { Thermal } \\
\text { energy } \\
\text { consumption, } \\
\mathrm{kW} \cdot \mathrm{h}\end{array}$ \\
\hline Cooling of indoor air to15 ${ }^{\circ} \mathrm{C}$ & 8 & 6.91 & 55.28 \\
\hline Operation with reduced heat losses (standby heating) & 28 & 85.3 & 2388 \\
\hline $\begin{array}{l}\text { Extra-heating (increase in the internal air temperature to } 20 \\
{ }^{\circ} \mathrm{C} \text { ) }\end{array}$ & 12 & 149.65 & 1795 \\
\hline Total & 48 & & 4238.28 \\
\hline Operation without standby heating & 48 & 99.5 & 4776 \\
\hline Thermal energy savings & & & 537.72 \\
\hline
\end{tabular}

Table 2

Changes in the heating system power and the thermal energy consumption when changing the outdoor temperature from $t_{\text {out_air }}=-15^{\circ} \mathrm{C}$ to $-17^{\circ} \mathrm{C}$ (Fig.1)

\begin{tabular}{|l|c|c|c|}
\hline \multicolumn{1}{|c|}{ Mode } & $\begin{array}{c}\text { Time, } \\
\text { hours }\end{array}$ & $\begin{array}{c}\text { Heating } \\
\text { system } \\
\text { power, } \mathrm{kW}\end{array}$ & $\begin{array}{c}\text { Thermal energy } \\
\text { consumption, } \\
\mathrm{kW} \cdot \mathrm{h}\end{array}$ \\
\hline Cooling of indoor air to $15^{\circ} \mathrm{C}$ & 8 & 43.95 & 351.6 \\
\hline Operation with reduced heat losses (standby heating) & 28 & 90.97 & 2547.16 \\
\hline $\begin{array}{l}\text { Extra-heating (increase in the internal air temperature to } \\
20^{\circ} \mathrm{C} \text { ) }\end{array}$ & 12 & 155.24 & 1862.88 \\
\hline Total & 48 & & 4761.64 \\
\hline Operation without standby heating & 48 & 105.2 & 5049.6 \\
\hline Thermal energy savings & & & 287.96 \\
\hline
\end{tabular}




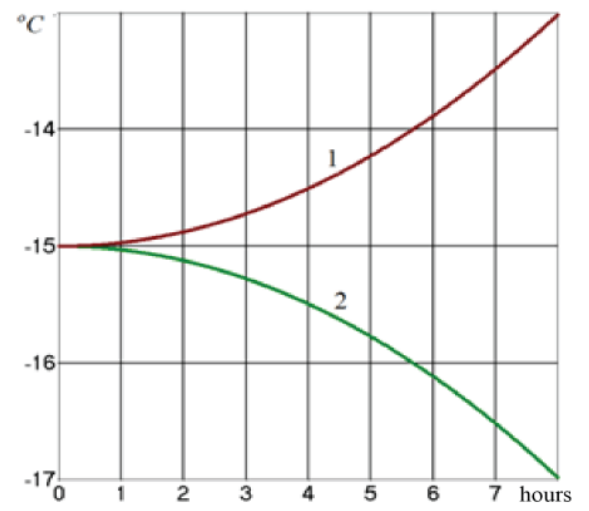

Fig. 1. Change in outdoor temperature over time: 1 - during warming; 2 - during cooling

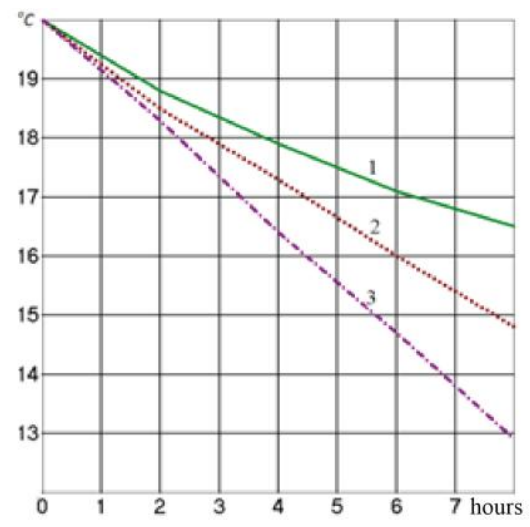

a)

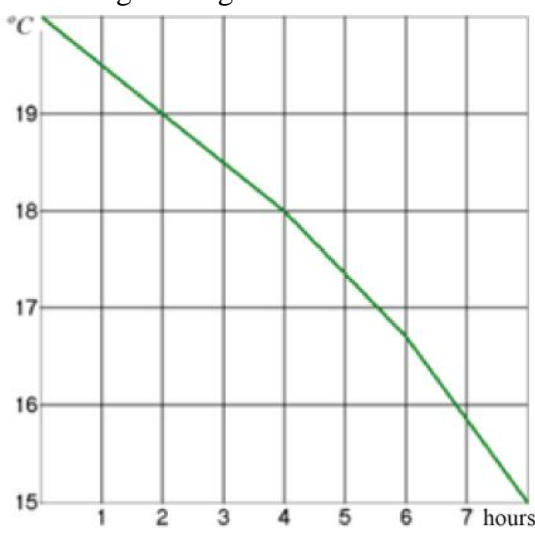

b)

Fig. 2. Changes in indoor temperature during 8 hours:

a) for a complete heating shutdown; b) for standby heating.

Curve 1 was obtained when outdoor air temperature increased from $t_{\text {out_air }}=-15{ }^{\circ} \mathrm{C}$ to $-13{ }^{\circ} \mathrm{C}$;

curve 2 is for $t_{\text {out_air }}=-15^{\circ} \mathrm{C}$; curve 3 was obtained when outdoor air temperature decreased from

$$
t_{\text {out_air }}=-15^{\circ} \mathrm{C} \text { to }-17^{\circ} \mathrm{C}
$$

From experimental relationships between the indoor air temperature and time, obtained when the heating was completely turned off, time constants $T$ can be determined $[14,15,16]$. Indoor air temperature maintenance at a given level should be ensured in a wide range of the outdoor air temperature changes due to a corresponding change in the temperature of direct network water according to the temperature schedule. It should be noted that the temperature of direct water will vary with a certain delay in time due to the inertia of the heating system and transport delay. Therefore, in the existing control algorithms according to the network water temperature schedule, the required power of the heating system is achieved using proportionalintegral and proportional-integral-differential laws of regulation not immediately, but with some delay $[16,17,18]$.

The mathematical model developed in this work allows studying the operation modes at constant and variable power of the heating system. The adaptive control algorithm allows one to reach any given heating mode, including during standby and forecast control, without using the parameters of the temperature schedule and the parameters of proportional-integral and proportional-integral-differential laws of regulation. 
To maintain a constant room temperature for a given time interval $\tau_{k}$, the coefficient $K$ and calculated power of the heating system can be determined by solving equation (7) from the condition that the indoor air temperature is equal at the beginning and at the end $t_{\text {in_airk }}=t_{\text {in_air0 }}$ of a certain time interval $\tau_{k}$. During this interval, the power of the heating system is assumed to be constant over time. Table 3 shows the forecasted heat loss power and the estimated power of the heating system during cooling and warming.

Figure 3 presents the calculated relationships between the internal air temperatures during cooling and warming and time at the heating system power determined using the mathematical model (curves 1) and the heating system power equal to the heat loss power at the beginning (curves 3 ) and at the end (curves 2) of the considered time interval .

Table 3

Changes in the forecast and calculated power of the heating system during the outdoor air cooling and warming

\begin{tabular}{|c|c|c|c|c|c|}
\hline $\begin{array}{c}\text { Change in outdoor } \\
\text { temperature over a } \\
\text { specified time } \\
\text { interval } \tau_{k}(8 \\
\text { hours }\end{array}$ & $\begin{array}{c}\text { Outdoor } \\
\text { temperature at } \\
\text { the beginning } \\
\text { of the } \\
\text { calculation } \\
\text { interval, }{ }^{\circ} \mathrm{C}\end{array}$ & $\begin{array}{c}\text { Outdoor } \\
\text { temperature } \\
\text { at the end of } \\
\text { the } \\
\text { calculation } \\
\text { interval, }{ }^{\circ} \mathrm{C}\end{array}$ & $\begin{array}{c}\text { Predicted } \\
\text { heat loss } \\
\text { power at the } \\
\text { beginning } \\
\text { of the } \\
\text { calculation } \\
\text { interval, } \mathrm{kW}\end{array}$ & $\begin{array}{c}\text { Predicted } \\
\text { heat loss } \\
\text { power at the } \\
\text { end of the } \\
\text { calculation } \\
\text { interval, } \mathrm{kW}\end{array}$ & $\begin{array}{c}\text { Estimated power } \\
\text { determined from } \\
\text { a mathematical } \\
\text { model, } \mathrm{kW}\end{array}$ \\
\hline Cooling & -15 & -17 & 99.5 & 105.9 & 135 \\
\hline Warming & -15 & -13 & 99.5 & 93.8 & 62.5 \\
\hline
\end{tabular}

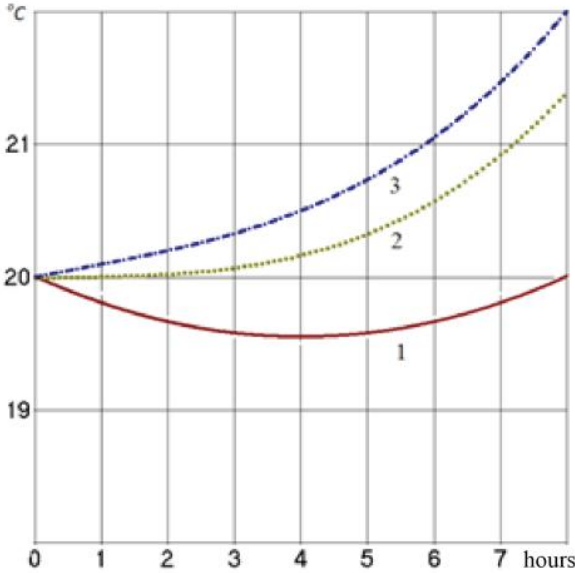

a)

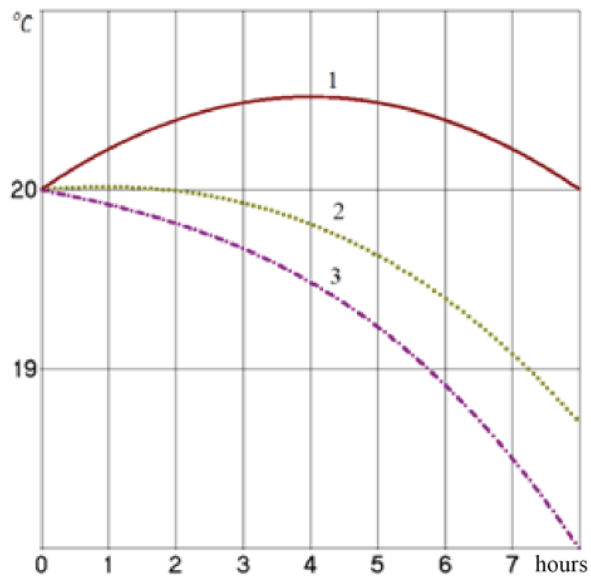

b)

Fig. 3. Dependence of indoor air temperature on time during warming (a) and cooling (b)for various heating system powers: 1 - power,

determined from a mathematical model; 2 - power equal to losses at the end of the time interval; 3 - power equal to losses at the beginning of the time interval

From fig. $3 b$ (curve 2) it can be seen that setting the heating system power equal to the heat loss power at the end of the cooling interval does not provide a constant indoor air temperature of $20{ }^{\circ} \mathrm{C}$ and causes under-heating; during warming, setting the heating system power equal to the loss power at the end of the selected interval (Fig. 3a, curve 2) causes the set temperature to be exceeded, i.e. extra-heating. Similar phenomena, but more pronounced are observed when the power of the heating system is set equal to the heat loss power at the beginning of the interval. Therefore, in case of forecast heating, to stabilize the temperature of the indoor air, it is necessary 
to set not the powers corresponding to the predicted temperatures of the outside air at the end of the considered time interval, but the power determined using mathematical model, which takes into account the thermal inertia of the enclosing structures. During cooling, the calculated power is greater than the heat loss power at the end of the period under consideration, during warming it is less, which is explained by the influence of heat accumulated by the building envelope. Therefore, forecast heating control $[16,17,18]$ should be proactive taking into account the thermal inertia of the building. Studies using a mathematical model showed that in order to maintain a constant temperature of indoor air in a room, it is necessary to set not the forecasted temperatures of the outdoor air, but the calculated ones $t_{\text {calc.out }}$, which, under cooling, are lower than the forecasted outdoor air temperature at the end of the considered time interval, but under warming they are higher. The calculated outdoor temperature can be determined from the expression

$$
t_{\text {calc.out }}=\frac{q V t_{\text {calc.in }}-K P_{\text {loss }}}{q V},
$$

where $P_{\text {loss }}$ is the heating network power at the beginning of the considered interval.

The calculated outdoor temperatures necessary to maintain the indoor air temperature at a given level are greatly influenced by the time constants of buildings and construction. So, for example, for a time constant $T=48$ hours, when the outdoor temperature decreases by 2 degrees from $-15{ }^{\circ} \mathrm{C}$ to $-17^{\circ} \mathrm{C}$, the calculated temperature $t_{\text {calc.out }}=-28{ }^{\circ} \mathrm{C}$, and when it is increased by 2 degrees $t_{\text {calc.out }}=-1.97{ }^{\circ} \mathrm{C}$. With a decrease in the time constant to 24 hours for the same conditions, the calculated outdoor temperatures are $-22^{\circ} \mathrm{C}$ and $-7.97{ }^{\circ} \mathrm{C}$, respectively. Thus, with a decrease in the time constant, which occurs with a decrease in the mass and thermal resistance of the building enclosures, the calculated temperatures approach the outdoor air temperatures at the end of the considered time interval, and the coefficient $K$ tends to 1 .

Mathematical models, algorithms for standby heating and maintaining at a given level the heating system power during forecast control can be implemented using PLC. The adaptive control algorithm uses continuously measured temperatures of indoor and outdoor air, and also allows setting the calculated temperature of the outdoor air and the required temperature of the indoor air to provide a comfortable temperature in the room as settings for air temperatures $[4,13]$. With forecast control, the mathematical model allows determining the heating system power and the ambient temperature settings, at which the indoor air temperature will remain almost constant when the outdoor temperature changes without under-heating and extra-heating.

\section{Conclusions}

The proposed mathematical model of unsteady processes in heat-resistant enclosures allows the forecast and standby heating to be adapted according to the adaptive control algorithm, taking into account the change in the temperature of the outdoor air over time. When calculating the modes of forecast and standby heating, the mathematical model allows, at given initial and final temperatures of the internal air, determining heating system power that provide the desired temperature at the end of a given period of time. For the standby heating, this is the temperature at the end of the cooling or warming interval. The developed adaptive control algorithm allows one to provide any design conditions and create an energy-efficient heating system that provides a given temperature in the building's premises with minimal heat consumption, taking into account all the parameters that affect the heat loss power and the heating system capacity.

The created experimental installation for monitoring and controlling the heat supply regimes of a building allows, faster than the known algorithms, achieving equality of the actual power of the heating system and the power of heat losses when weather conditions change, to implement any adaptive control algorithms without setting the temperature parameters of the network water. 


\section{References}

1. Oldewurtel F, Sturzenegger D, Morari M. Importance of building climate control. Applied energy. 2013; 101 (1):521-532.

2. Livchak VI. The choice of priority in the automatic regulation of heat transfer from heating systems of residential buildings. Engineering systems. 2016 AVOK North-West. 2016;. (1):3845.

3. Panferov VI, Trenin NA, Panferov SV. On the assessment of heat saving reserves in the automation of building heating systems. News of heat supply. 2017; (9):46-49. (In Russ).

4. Tarasova VV, Afanasyev VV, Kovalev VG, Tarasov VA, Kalinin AG. Adaptive control of the mode of heat supply of a building with the help of an automated heat supply station. Vestnik chuvashskogo universiteta. 2016; (3):117-123. (In Russ).

5. Cherkasova OA, Malkin VV, Sabischansky IA, Merkulov PN. Automatic control of optimal hydraulic modes of heating systems. News of heat supply. 2019; (1):21-25. (In Russ).

6. Puhkal VA. Analysis of heat consumption for heating residential buildings in operation. Fundamental research. 2017; (1):106-111. Available at the journal.URL: http://fundamentalresearch.ru/ru/article/view?id=41323 Accessed to: 31 March 2019.

7. Shaikh PH, Nor NM, Nallagownden P, Elamvazuthi I., Ibrahim T. of Smart Sustainable Buildings. Renewable and Sustainable Energy Reviews, 2014;34:409-429. doi: 10.1016 / j.rser.2014.03.027

8. Zakharov AA, Zakharova IG, Romazanov AR, Shirokikh AV. Thermal mode modeling and heat supply management of the premises of a smart building. Bulletin of Tyumen State University. Physical and mathematical modeling. Oil, gas, energy. 2018; 4(2):105-119. doi: 10.21684 / 24117978-2018-4-2-105-119.

9. Anvari-Moghaddam A, Monsef H, Rahimi-Kian A. Cost-Effective and Comfort-Aware Residential Energy Management under Different Pricing Schemes and Weather Conditions. Energy and Buildings. 2015. (86): 782-793. doi: 10.1016 / j.enbuild.2014.10.017.

10. Ascione F, Bianco N, Stasio CDe, Mauro GM, Vanoli GP. Simulation-Based Model of the Predictive Control of Energy and Thermal Comfort. Energy and Buildings. 2016; (111):131-

\section{Литература}

1. Oldewurtel F., Sturzenegger D., Morari M. Importance of occupancy information for building climate control // Applied energy. 2013. 101(1). pp.521-532.

2. ЛивчакВ.И. Выбор приоритета в авторегулировании и теплоотдачи систем отопления жилых зданий // Инженерные системы. 2016 АВОКСеверо-Запад. 2016. № 1. С.38-45.

3. Панферов В.И., Тренин Н.А., Панферов С.В. К оценке резервов экономии теплоты при автоматизации систем отопления зданий // Новости теплоснабжения. 2017. №9. С.46-49.

4.Адаптивное управление режимом теплоснабжения здания с помощью автоматизированного теплового пункта/ В.В. Тарасова, В.В. Афанасьев, В.Г. Ковалев, В.А. Тарасов, А.Г. Калинин // Вестник Чувашского университета. 2016. № 3. С.117-123.

5. Черкасова О.А., Малкин В.В., Сабищанский И.А., Меркулов П.Н. Автоматическое управление оптимальными гидравлическими режимами систем теплоснабжения // Новости теплоснабжения. 2019. №1.C.21-25.

6.Пухкал В.А. Анализ режимов теплопотребления на отопление эксплуатируемых жилых зданий // Фундаментальные исследования. 2017. № 1. С. 106-111. Доступно по URL: http://fundamentalresearch.ru/ru/article/view?id=41323. Ссылка активна на: 31марта 2019.

7. Shaikh P.H., Nor N.M., Nallagownden P., Elamvazuthi I., Ibrahim T. A Review on Optimized Control Systems for Building Energy and Comfort Management of Smart Sustainable Buildings. Renewable and Sustainable Energy Reviews, 2014. Vol. 34. pp. 409-429.

8. Захаров А.А., Захарова И.Г., Ромазанов А.Р., Широких А.В. Моделирование теплового режима и управление теплоснабжением помещений умного здания // Вестник Тюменского государственного университета.

Физикоматематическоемоделирование. Нефть, газ, энергетика. 2018. Т4. № 2. С. 105-119.

9. Anvari-Moghaddam A, Monsef H, Rahimi-Kian A. Cost-Effective and Comfort-Aware Residential Energy Management under Different Pricing Schemes and Weather Conditions // Energy and Buildings. 2015. Vol. 86. pp. 782-793.

10.Ascione F. Simulation-Based Model Predictive Control by the Multi-Objective Optimization of Building Energy Performance and Thermal Comfort / 
144. doi: 10.1016 / j.enbuild.2015.11.033.

11. Ock J, Issa RRA, Flood I. Smart building energy management systems (BEMS) simulation conceptual framework. Proceedings of the 2016 Winter Simulation Conference. IEEE Press, 2016. pp. 3237-3245. doi: 10.1109 / WSC.2016.7822355. 12. Senave MA. Reynders G, Verbeke S, Saelens D. Simulation exercise to improve building energy performance characterization via on-board monitoring. Energy Procedia. 2017; 132:969-974. doi: 10.1016/j.egypro.2017.09.687.

13. Tarasova VV, Tarasov VA, Kalinin AG, Afanasyev VV, Kovalev VG. Study of the dynamic characteristics of the automatic heating control system of a building. Bulletin of the Chuvash University.Natural and Technical Sciences. 2015; 3:122-128. (In Russ).

14. Panferov VI, Anisimova EYu, Nagornaya AN. To the theory of mathematical modeling of the thermal regime of buildings. Bulletin of the South Ural State University. Chelyabinsk. 2006. 14:128133. (In Russ).

15.Abdullin VV, Shnayder DA, Basalaev AA. Building Heating Feed-Forward Control Based on Indoor Air Temperature Inverse Dynamics Model. Lecture Notes in Engineering and Computer Science: Proceedings of The World Congress on Engineering and Computer Science 2014, WCECS 2014, 22-24 October, 2014, San Francisco, CA, USA, pp. 886-892.

16. Akhmetov ER. Analysis of the model of duty heating as an energy-saving measure. Energy saving and energy efficiency. 2014. 5(59): 25-28. (In Russ).

17. Dobrotin SA, Prokopchuk EL. Synthesis of a system of anticipatory control of the process of supplying heat to a building's heating. Problems of Regional Publisher: Institute of Energy of the Academy of Sciences of Moldova Energy (Kishinev). 2011. N2 .pp. 53-65. (In Russ).

18. Rumyantsev D.V., Tverskoy M.M. Algorithm of proactive control of thermal processes of a building with a combined heating system. Basic Research. 2015.2(24):5371-5376. Available at: http://fundamental-

research.ru/ru/article/view?id=38352. Accessed to 27 March 2019.
F. Ascione, N. Bianco, C. De Stasio, G. M. Mauro, G. P. Vanoli // Energy and Buildings. 2016. Vol. 111. pp. 131-144.

11.Ock J. Smart building energy management systems (BEMS) simulation conceptual framework / J. Ock, R. R. A. Issa, I. Flood // Proceedings of the 2016 Winter Simulation Conference. IEEE Press, 2016. pp. 32373245. doi: 10.1109/WSC.2016.7822355.

12.Senave M. A Simulation exercise to improve building energy performance characterization via onboard monitoring / M. Senave, G. Reynders, S. Verbeke, D. Saelens // Energy Procedia. 2017. Vol. 132. pp. 969-974.

13.Тарасова В.В., Тарасов В.А., Калинин А.Г., Афанасьев В.В., Ковалев В.Г. Исследование динамических характеристик системы автоматического регулирования отопления здания. Вестник Чувашского университета. Естественные и технические науки 2015. № 3, С.122-128

14.Панферов В.И., Анисимова Е.Ю., Нагорная А.Н. К теории математического моделирования теплового режима зданий // Вестник ЮжноУральского государственного университета. Челябинск. 2006. №14. С.128-133.

15.Abdullin V.V., Shnayder D.A., Basalaev A.A. Building Heating Feed-Forward Control Based on Indoor Air Temperature Inverse Dynamics Model. Lecture Notes in Engineering and Computer Science: Proceedings of The World Congress on Engineering and Computer Science 2014, WCECS 2014, 22-24 October, 2014, San Francisco, CA, USA, pp. 886-892. 16.Ахметов Э.Р. Анализ модели работы дежурного отопления как энергосберегающего мероприятия // Энергоресурсосбережение и энергоэффективность. 2014. № 5 (59). С.25-28.

17.Добротин С. А. , Прокопчук Е. Л. Синтез системы упреждающего управления процессом подачи тепла на отопление здания // Проблемы региональной энергетики. 2011. №2. С. 53-65 Издательство: Институт энергетики Академии наук Молдовы (Кишинев).

18.Румянцев Д.В., Тверской М.М. Алгоритм упреждающего управления тепловыми процессами здания при комбинированной системе отопления // Фундаментальные исследования. 2015. № 2-24. С. 5371-5376. Доступен по URL: http://fundamentalresearch.ru/article/view?id=38352 .Ссылка активна на: 27 марта 2019. 


\section{Authors of the publication}

Vladimir A. Tarasov - $\mathrm{PhD}$ in Engineering sciences, Associate Professor Chuvash State University, Cheboksary, Russia. E- mail: vladimir_tarasov@inbox.ru.

Valentina V. Tarasova - software engineer LLC Engineering and Technical Center GORISS, Cheboksary, Russia. E- mail: charming_cerl@rambler.ru

Vladimir V. Afanasyev - Grand $\mathrm{PhD}$ in Engineering sciences, Associate Professor Chuvash State University, Cheboksary, Russia. E- mail: avvteo@mail.ru.

Vladimir G. Kovalev - $\mathrm{PhD}$ in Engineering sciences, Associate Professor Chuvash State University, Cheboksary, Russia. E- mail: espp21@mail.ru

Viktor N. Orlov - PhD in Physico-mathematical sciences, Professor Chuvash State University, Cheboksary, Russia. E- mail: orlov.vick@yandex.ru. 